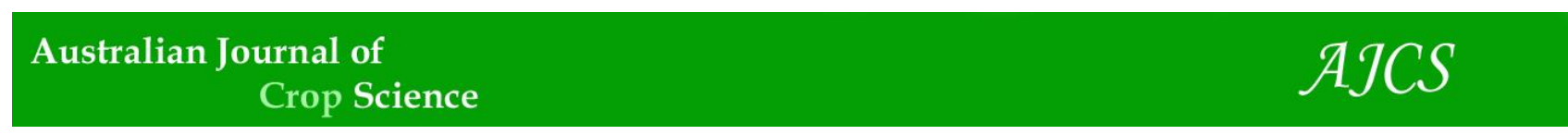

AJCS 12(05):749-754 (2018)

ISSN:1835-2707

doi: 10.21475 /ajcs.18.12.05.PNE880

\title{
Phenotypic divergence of grapes using productive cycle
}

\section{Mara Fernandes Moura ${ }^{1}$, Lenon Romano Modesto ${ }^{2 *}$, Carlos Tadeu dos Santos Dias ${ }^{3}$, José Luiz Hernandes ${ }^{1}$, Miguel Zagretti Saito ${ }^{1}$, Taiane Silva Santos ${ }^{1}$}

${ }^{1}$ Instituto Agronômico/IAC - Center APTA of Fruits, C.P. 13214-820 - Jundiaí, SP - Brazil

${ }^{2}$ Federal University of Santa Catarina/UFSC - Vegetable Genetic Resources, C.P. 88.034-001 - Florianópolis - SC -

Brazil

${ }^{3}$ University of São Paulo/ESALQ - Dept. of Estatistic, C.P. 13418-900 - Piracicaba, SP - Brazil

*Corresponding author: lenon_modesto@hotmail.com

\begin{abstract}
Classifying vines regarding the number of days required to complete de productive cycle and the duration of intermediate phenologic phases are essential for genetic improvement programs, implementation of cultivation techniques and handling of the grape harvest. The objective of this study was to evaluate the access phenotypic divergence of grapes from the germplasm collection by the Agronomic Institute - IAC. Evaluations were performed for 4 years of production, from 2012 to 2015, when the plants were 4 years old. The training system applied the espalier, at a $2.0 \times 1.0 \mathrm{~m}$ spacing between lines and plants, respectively. The IAC's grape germplasm collection comprised 110 varieties of the Vitis vinifera, Vitis labrusca species and inter-specific hybrids grafted into the IAC 766 rootstocks, being 3 plants per each variety. After the pruning of the main vine phonologic phases, the number of days was evaluated using the scale proposed by Eichhorn and Lorenz. Two evaluations a week were carried out until the flowering, and afterwards one evaluation was performed a week, the period between pruning and the beginning of sprouting, full flowering with $50 \%$ flowers opened, beginning of maturation (veraison) and maturation (harvest), visually mature fruits and content of soluble solids above 14Bix. Multivariate analysis, such as the correlation between varieties, analysis of the main components (PCA) and methods of non-weighted arithmetic means (UPGMA) was applied to classify the phenotypes according to the productive cycle. A relation was found between the sprouting and the flowering phases, as well as the starting maturation and maturation. The first two components explained $81 \%$ of the total variability, being that the starting maturation and maturation were the best variables to study the divergence of vine phenotypes. Also, combining the UPGMA method and the PCA analysis that distinguished three groups, allowed us to divide the phenotypes into 25 processes, 75 median and 10 late varieties, according to their productive cycle. It was possible to conclude that the techniques used to study the genetic diversity applied to phenologic characters were effective to evaluate the vines phenotypic divergence, and therefore, the multivariate analysis may be used to guide future vine improvement programs.
\end{abstract}

Keywords: phenology, genetic resources, germplasm, plant breeding, variability.

Introduction

Grape is a very important culture in the world because of the production of wine, juice, fresh and dried fruits (Migicovsky et al., 2016). But similar to all perennial species, it needs a considerably long time to develop new varieties since maturity often requires several growing seasons until breeding success may be evaluated (Sánchez-Mora et al., 2017). However, nowadays there are many biotechnological techniques that advance this process (Töpfer et al., 2011).

The genetic variability of a grape germplasm bank can only be effectively used when properly evaluated and quantified, and describing the inputs or genotypes is required for maintaining and characterizing both (Vanderborght 1988). Characterizing and evaluating germplasm, as well as providing better knowledge of available assessments, is essential for a more intense usage in later phases, allowing the identification of duplicate genotypes and simplifying subsequent work. In a genebank, it is possible to establish a core collection, which by definition covers with minimal redundancy the genetic diversity in cultivated and related wild species, besides allowing the identification of reproduction modes prevailing in individual genotypes (Gama et al., 2013).

In the scenario of breeding, conservation of genetic resources and the preservation of genetic diversity, germplasm characterization for immediate or future use is a very important approach that makes it possible to identify desirable developmental characteristics that increase productivity and resistance of the cultivar to the main pathogens affecting the culture. The choice of germplasm is a fundamental and crucial element in any plant breeding program, whether for the development of cultivars to be used in hybrids or for basic studies, which may significantly impact on the success or failure of the selection process (Wan et al., 2015). 
The plant phenology that allows characterizing the duration of vine development phase concerning climate, especially with seasonal variations, may also be used to interpret how the different climatic regions influence the culture and are relevant for the genetic breeding programs (Leão et al., 2011). Moreover, this evaluation is also relevant since the climate changes are affecting vineyard in many parts of the world (Van Leeuwen and Darriet, 2015).

Multivariate data analysis, as opposed to other univariate statistical methods, consider multiple variables at the same time, revealing the important components through multiple interference and interactions used in scientific works as a tool allowing the classification and characterization of the genetic material (Leão et al., 2011; Borges et al., 2010; Cozzolino et al., 2009).

Many grape breeding programs search for climatic adaptation because that is very correlated with diseases attack and fruit quality. Considering the importance of knowing the grapes phenotypic divergence, the objective of this paper is to classify the productive cycle of 110 phenotypes for genetic breeding. Studying plant phases made it possible to cross different genotypes, breeding new varieties and understanding the better period to plant some cultivars. Furthermore, when knowing the number of days to harvest the grape enables cultivated new varieties in different regions.

\section{Results and discussion}

\section{Correlation analysis}

Correlations between the variables are shown in Table 1 . The sprouting phase (S) was significantly correlated with flowering (F), because the initial sprouting produced branches, leaves, and flowers, but the differences between the vines in the vineyard can be decreased or increased by the weather, in particular by temperature and precipitation at the moment of budding (Lebon et al., 2005).

Under normal temperate climates and good growing conditions, the starting sprouting time and inflorescence development rate depend on the bud position on the branch in the winter, some flowers per inflorescence and the genetic potential (Vasconcelos et al., 2009).

In order to develop branches and flowers, the plant needs to overcome bud dormancy, and the latency of the gem of the vines is genetically controlled and naturally induced by photoperiod and low temperatures (Barros et al., 2007). In the State of São Paulo, as well as in other cities of Brazil and worldwide, the practice of applying plant regulator on the vine to overcome dormancy after pruning is usual to make possible the cultivation of different species of Vitis spp. in conditions where the climate does not properly reach cold temperatures (George et al., 1988; Or et al., 2000; Or et al., 2002; Halaly et al., 2008; Arora et al., 2003).

The sprouting and flowing phases are not correlated with the starting maturation (SM) and maturation (M), but the starting maturation was correlated with the maturation (Table 1 and Fig 1).

The start maturation and maturation are important phases for grapes, because of increasing in grape size, $\mathrm{pH}$, glucose, fructose, anthocyanins and flavour compound contents and decreases tartrate and tannins (Coombe 2001). Furthermore, this two phases involved control of the timing of ripening, berry size, coloration, acidity and the relative assortment of volatile and non-volatile aroma and flavour compounds, fundamental in table and wine grape cultivars (Conde et al., 2007).

Many factors can influence the point at which maturation starts, but some authors describe the importance of climactic and genetic factors (Agasse et al., 2007; Coombe 2001; Conde et al., 2007). The genetic factors are associated with a breeding to provide new adapted cultivars or to choose genotypes with interesting characteristics for grapeproducing regions (Agasse et al., 2007). Moreover, the climate factor is related to water availability in the soil, because the volumetric growth of fruit is primarily the result of water accumulation; hence, the maintenance of fruit growth requires coordination between water and solute transport, both through the vascular tissue and at the individual cells level (Leblon et al., 2005, Taiz and Zaiger 2009).

\section{Principal component analysis and UPGMA}

According to the principal component analysis (PCA), the first two principal components accounted for $81 \%$ (Table 2) of the variation in genotypes, a condition that allows analyzing divergence through graphic dispersion (CerqueiraSilva et al., 2009). Also, regarding the productive cycle, it was possible to classify the genotypes into three groups, early, median and late (Fig 1).

The first component was associated with the starting maturation (SM) and maturation (M) phases. The second component was associated with the sprouting (S) and flowering $(F)$ variable (Table 2).

According to Castelli and Pisani (1985), the sprouting and flowering process apparently varies among varieties of grapes, but the last two phenological periods, starting maturation and maturation, are highly correlated, with a greater influence on the classification of genotypes regarding the number of days taken to complete the productive cycle (Table 1 and Fig 1 ). Thus, the genotypes might be divided into early, median and late cycle. The varieties that showed the lowest starting maturation also showed low values for maturation, and the interval between these two phenological phases is small when compared with the preceding phases, flowing and sprouting.

Between the starting maturation and maturation phases, the grape berries undergo metabolic and physiological changes, and the range of these phenologic phases covers the period from early colour change (for red grapes), or translucency of the berries (for white grapes) until the harvest, ranging from 30 to 70 days, depending on the variety, rootstock, and region of cultivation (Abe et al., 2007).

Within the group classified as early cycle are 25 genotypes of hybrid species, Vitis vinifera and Vitis labrusca (Fig 1). These plants showed lower phases starting maturation and maturation and completed the cycle between 112 and 132 days. Among the best-known varieties of this group are BRS Linda, BRS Morena, Einset Seedless, Muska, Kioho I., Venus, Maria, Mars, IAC Aurora, Moscatel Azul, Moscatel Suiça, 
Table 1. Correlations between four phenological phases of 110 grape phenotypes in four year cycles.

\begin{tabular}{lcccc}
\hline Phases & Sprouting & Flowering & Starting maturation & Maturation \\
\hline Sprouting & 1 & $0.44^{*}$ & 0.20 & -0.01 \\
Flowering & & 1 & 0.01 & 0.26 \\
Starting maturation & & & 1 & $0.78^{*}$ \\
Maturation & & & & 1 \\
\hline
\end{tabular}

*diference significant at $p \leq 0.01$.

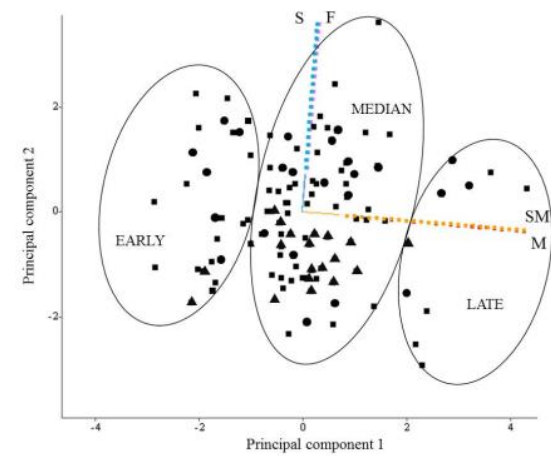

Fig 1. Principal components analysis showing the relation between the two main components and the four phenological phases, sprouting, flowering, starting maturation and maturation, divided the phenotypes about them productive cycle in three groups, early, median and late cycles. Types of grapes: Hybrid ( $\mathbf{\square})$, Vitis vinifera $(\bullet)$ and Vitis labrusca (• ). (S) sprouting, (F) flowering, (SM) starting maturation and (M) maturation.

Table 2. Estimates of eigenvalues and eigenvectors associated with the principal components analysis, along with their relative and accumulated importance, relative to four phenological phases valued at 110 grape phenotypes in four cycles.

\begin{tabular}{|c|c|c|c|c|c|c|c|c|}
\hline \multirow{2}{*}{ Components } & \multicolumn{4}{|c|}{ Eigenvectors } & \multirow{2}{*}{ Eigenvalues } & \multirow{2}{*}{ Difference } & \multirow{2}{*}{$\begin{array}{c}\text { Proportion } \\
\text { (\%) }\end{array}$} & \multirow{2}{*}{$\begin{array}{c}\text { Accumulated } \\
(\%)\end{array}$} \\
\hline & $\mathrm{M}$ & SM & $\mathrm{F}$ & $\mathrm{S}$ & & & & \\
\hline 1 & 0.705 & 0.705 & 0.062 & 0.053 & 1.79 & 0.34 & 45 & 45 \\
\hline 2 & -0.059 & -0.056 & 0.704 & 0.705 & 1.44 & 0.88 & 36 & 81 \\
\hline 3 & -0.349 & 0.044 & -0.706 & 0.706 & 0.56 & 0.34 & 14 & 95 \\
\hline 4 & 0.706 & -0.706 & -0.038 & 0.041 & 0.22 & & 5 & 100 \\
\hline
\end{tabular}

Note: (S) sprouting, (F) flowering, (SM) starting maturation and (M) maturation.

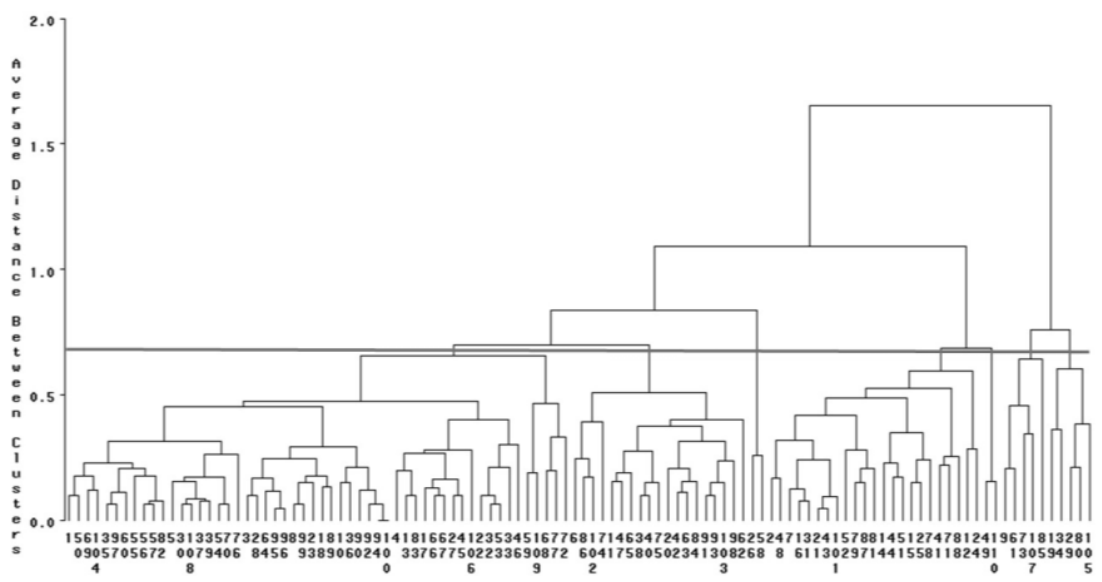

Fig 2. UPGMA tree of 110 grapes phenotypes using four phenological periods, sprouting, flowering, starting maturation and maturation, with the cut was made on the shaft at a distance of approximately 0.7 , classifying them into three groups about the number of days to complete the cycle. Note: (1) Alphonse Lavalee, (2) Alwood, (3) Ananaz, (4) Arizul L, (5) Armênia, (6) Armênia 170060, (7) Athens, (8) August Giant, (9) Barrileta, (10) Beni-Fuji, (11) Benitaka, (12) Black Corintho, (13) Black Price, (14) BRS Linda, (15) BRS Morena, (16) Buffalo, (17) Carman, (18) Diamond, (19) Dona Zilá, (20) Dutchess, (21) Einset seedless, (22) Favorita, (23) Fern Munson, (24) Fiesta, (25) Flame seedless, (26) Fogarina, (27) Folha de Figo, (28) Golden Muscat, (29) Golden Queen, (30) H 4.49.69, (31) Hartford, (32) Hidalgo, (33) Highland, (34) Hubard, (35) IAC 1595-16, (36) IAC 0031-01, (37) IAC 0324-20, (38) IAC 0388, (39) IAC 0433-06, (40) IAC 0501-06, (41) IAC 0506-33, (42) IAC 0514-06, (43) IAC 0775-26, (44) IAC 0842-04, (45) IAC 0871, (46) IAC 0871-05 (47) IAC 0871-41, (48) IAC 1298-21, (49) IAC 1398-21, (50) IAC 1410-08, (52) IAC 1596-02, (53) IAC 1726-03, (54) IAC Juliana, (55) Igawa 0668, (56) Igawa 0682, (57) Igawa 1010, (58) Igawa 1011, (59) Igawa 1012, (60) Igawa 1015, (61) lowa, (62) Isabel Sport, (63) Itália, (64) Ita liana, (65) J 7602-66, (66) J 7604-15, (67) J7602-44, (68) Japonesa, (70) Kioho BG, (71) Kioho H, (71) Kioho I, (72) Lakemont seedless, (73) Líbano, (74) Liberty, (75) Lomanto, (76) Lubeck, (77) Lucile, (78) Maria, (79) Mars, (80) Moscatel Aragentina, (81) Moscatel Azul, (82) Moscatel de Hamburgo, (83) Moscatel de Oieiras, (84) Moscatel Nazareno, (85) Moscate Rosada Portuguesa, (86) Moscatel Rosado, (87) Moscatel Suíça, (88) Muska, (89) Niabell, (90) Niagara, (91) Niagara Branca Gigante, (92) Niagara Branca Oval, (93) Niagara Maravilha, (94) Niagara Rajada, (95) Niagara Rosada, (96) Niagara Rosada Escura, (97) Niagara Rosada Gigante, (98) Niagara Rosada Variegada, (99) Niagara seedless, (100) Niagara Steck, (101) Perla de Csaba, (102) Pirovana 54, (103) Portugais bleu, (104) Romana, (105) Rosaki, (106) Ruby seedless, (107) Tardia de Caxias, (108) Tieta, (109) Topaz e (110) Venus. 
Table 3. Grapes phenotypes classified by species and identification number.

\begin{tabular}{|c|c|c|c|c|c|}
\hline Number & Phenotype & Species & Number & Phenotype & Species \\
\hline 1 & Alphonse Lavallee & Vitis vinifera & 56 & Igawa 0682 & Hybrid \\
\hline 2 & Alwood & Vitis labrusca & 57 & Igawa 1010 & Hybrid \\
\hline 3 & Ananaz & Hybrid & 58 & Igawa 1011 & Hybrid \\
\hline 4 & Arizul L & Vitis vinifera & 59 & Igawa 1012 & Hybrid \\
\hline 5 & Armênia & Vitis vinifera & 60 & Igawa 1015 & Hybrid \\
\hline 6 & Armênia 170060 & Vitis vinifera & 61 & Iona & Hybrid \\
\hline 7 & Athens & Hybrid & 62 & Isabel Sport & Vitis labrusca \\
\hline 8 & August Giant & Hybrid & 63 & Itália & Vitis vinifera \\
\hline 9 & Barrileta & Hybrid & 64 & Italiana & Vitis vinifera \\
\hline 10 & Beni-Fuji & Vitis vinifera & 65 & J 7602-66 & Hybrid \\
\hline 11 & Benitaka & Vitis vinifera & 66 & J 7604-15 & Hybrid \\
\hline 12 & Black Corintho & Vitis vinifera & 67 & $J 7602-44$ & Hybrid \\
\hline 13 & Black Price & Vitis vinifera & 68 & Japonesa & Hybrid \\
\hline 14 & BRS Linda & Hybrid & 69 & Kioho BG & Hybrid \\
\hline 15 & BRS Morena & Hybrid & 70 & Kioho H & Hybrid \\
\hline 16 & Buffalo & Vitis labrusca & 71 & Kioho I & Hybrid \\
\hline 17 & Carman & Hybrid & 72 & Lakemont seedless & Hybrid \\
\hline 18 & Diamond & Vitis Labrusca & 73 & Líbano & Hybrid \\
\hline 19 & Dona Zilá & Hybrid & 74 & Liberty & Hybrid \\
\hline 20 & Dutchess & Vitis labrusca & 75 & Lomanto & Hybrid \\
\hline 21 & Einset seedless & Hybrid & 76 & Lubeck & Hybrid \\
\hline 22 & Favorita & Hybrid & 77 & Lucile & Hybrid \\
\hline 23 & Fern Munson & Vitis vinifera & 78 & Maria & Hybrid \\
\hline 24 & Fiesta & Vitis vinifera & 79 & Mars & Hybrid \\
\hline 25 & Flame seedless & Vitis vinifera & 80 & Moscatel Argentina & Vitis vinifera \\
\hline 26 & Fogarina & Hybrid & 81 & Moscatel Azul & Vitis vinifera \\
\hline 27 & Folha de Figo & Vitis labrusca & 82 & Moscatel de Hamburgo & Vitis vinifera \\
\hline 28 & Golden Muscat & Vitis vinifera & 83 & Moscatel de Oieiras & Vitis vinifera \\
\hline 29 & Golden Queen & Vitis vinifera & 84 & Moscatel Nazareno & Vitis vinifera \\
\hline 30 & H 4.49.69 & Vitis vinifera & 85 & Moscatel Rosada Portuguesa & Vitis vinifera \\
\hline 31 & Hartford & Hybrid & 86 & Moscatel Rosado & Vitis vinifera \\
\hline 32 & Hidalgo & Hybrid & 87 & Moscatel Suíça & Vitis vinifera \\
\hline 33 & Highland & Hybrid & 88 & Muska & Hybrid \\
\hline 34 & Hubard & Hybrid & 89 & Niabell & Vitis labrusca \\
\hline 35 & IAC 1595-16 & Hybrid & 90 & Niagara & Vitis labrusca \\
\hline 36 & IAC 0031-01 & Hybrid & 91 & Niagara Branca gigante & Vitis labrusca \\
\hline 37 & IAC 0324-20 & Hybrid & 92 & Niagara Branca Oval & Vitis labrusca \\
\hline 38 & IAC 0388 & Hybrid & 93 & Niagara Maravilha & Vitis labrusca \\
\hline 39 & IAC 0433-06 & Hybrid & 94 & Niagara Rajada & Vitis labrusca \\
\hline 40 & IAC 0501-06 & Hybrid & 95 & Niagara Rosada & Vitis labrusca \\
\hline 41 & IAC 0506-33 & Hybrid & 96 & Niagara Rosada Escura & Vitis labrusca \\
\hline 42 & IAC 0514-06 & Hybrid & 97 & Niagara Rosada Gigante & Vitis labrusca \\
\hline 43 & IAC 0775-26 & Hybrid & 98 & Niagara Rosada variegada & Vitis labrusca \\
\hline 44 & IAC 0842-04 & Hybrid & 99 & Niagara seedless & Vitis labrusca \\
\hline 45 & IAC 0871 & Hybrid & 100 & Niagara Steck & Vitis labrusca \\
\hline 46 & IAC 0871-05 & Hybrid & 101 & Perla de Csaba & Vitis vinifera \\
\hline 47 & IAC 0871-41 & Hybrid & 102 & Pirovano 54 & Vitis vinifera \\
\hline 48 & IAC 0871-41 & Hybrid & 103 & Portugais bleu & Vitis vinifera \\
\hline 49 & IAC 1398-21 & Hybrid & 104 & Romana & Vitis vinifera \\
\hline 50 & IAC 1410-08 & Hybrid & 105 & Rosaki & Vitis vinifera \\
\hline 51 & IAC 1595-02 & Hybrid & 106 & Ruby seedless & Vitis vinifera \\
\hline 52 & IAC 1596-02 & Hybrid & 107 & Tardia de Caxias & Híbrida \\
\hline 53 & IAC 1726-03 & Hybrid & 108 & Tieta & Hybrid \\
\hline 54 & IAC Juliana & Hybrid & 109 & Topaz & Hybrid \\
\hline 55 & Igawa 0668 & Hybrid & 110 & Venus & Hybrid \\
\hline
\end{tabular}

Perla de Csaba, Flame Seedless, Black Corinth, Fiesta, Alwood and Buffalo (Fig 2). The varieties Venus and Mars are American hybrids with early cycles (Camargo 1993; Botelho et al., 2002; Tecchio et al., 2009). Corroborating Borges et al., (2010) grouped into Semi-Arid Brazilian conditions the varieties, Flame Seedless and Fiesta, with $59 \%$ similarity in days to complete the cycle.

The values to reach the starting maturation and maturation phases concentrated near the central axis the principal components graphic, with the number of days to harvest ranging from 134 to 156 , classified as corresponding to the median cycle, including 75 genotypes of all species (Fig 1). Among the main ones are the varieties Arizul L., Beni Fugi, Diamond, Fogarina, Folha de figo (fig leaf), Hidalgo, IAC Juliana, Itália, Italiana, Kiono B.G., Lakemont seedless, Liberty, Lubeck, Moscato Hamburgo, Moscato Rosado, Niagara Branca, Niagara Rosada, Niagara Rajada, Niagara seedless, Portugal, Romana, Tieta and Topaz (Fig 2). 
In Turkey, the cultivation of Vitis labrusca, Niagara Branca presented a median cycle of approximately 148 days from budding to harvest (Köse 2014), and in Rio Grande do Sul, Brazil, the cultivation of Niagara Rosada and Niagara Branca also presented a white median cycle of approximately 147 days of budding to harvest (Anzanello et al., 2012).

The 10 genotypes classified as late cycle presented the highest values to reach the starting maturation and maturation phases, ranging from 156 to 174 days to complete the cycle (Fig 1). Among them are Barrilete, Dona Zilá, Golden Queen, Highland, Iona, Líbano, Moscato Argentina, Moscato Rosada Portuguesa, Rosaki Rosada and Tardia de Caxias varieties (Fig 2). According to Shiraishi (2000), the Rosaki variety features a longer cycle when compared with Buffalo, an early cycle variety. Corroborating, the genotypes Dona Zilá and Tardia de Caxias feature a longer cycle of 20 more days to harvest compared with the Niagara Rosada, a median cycle variety (Camargo et al., 1994).

These results can be better viewed on the dendrogram graphic (Figure 2), where a group comprised of the same varieties, having a cut on the shaft at a distance of approximately 0.7 , classifying them into three groups regarding the number of days to complete the cycle. It can be observed that the shortest distance between genotypes was 0 , between Niagara Rajada and Niagara Steck varieties, two median cycle cultivars that are both somatic mutations of the Niagara Branca variety (Souza 1959), and the greatest distance was 0.3604 between Dona Zilá and Highland varieties, classified as a late cycle.

\section{Materials and methods}

\section{Experimental area and plant material}

The active collection of germplasm of Vitis spp located in the Agronomic-IAC, Brazil, situated at $23^{\circ} 06^{\prime \prime}$ South, 46 $56^{\prime \prime}$ West, at an altitude of $745 \mathrm{~m}$, with pluvial precipitation of $1400 \mathrm{~mm}, 19.5{ }^{\circ} \mathrm{C}$ temperature, and $70.6 \%$ yearly median relative humidity. The climate is classified as Cwa, and the soil as Dystrophic Cambisols.

We analyzed the phenological behaviour of 110 genotypes of grape, commercial and non-commercial varieties belonging to the species Vitis vinifera, Vitis labrusca and hybrids among them, during production 4 years, from 2012 to 2015 , to classify them regarding the productive cycle of the varieties presented in the germplasm grape collection; these are identified by the numbers 1 to 110 (Table 3).

The vines were grafted onto rootstock IAC 766 'Campinas', conducted in espalier and spaced in $2.0 \mathrm{~m}$ between lines and $1.0 \mathrm{~m}$ between plants. Each genotype consisted of three plants pruned every year during the month August, leaving one or two gems per branch. Hydrogenated cyanamide $\left(\mathrm{H}_{2} \mathrm{CN}_{2}\right.$ Dormex, $\left.49 \%\right)$ was applied by targeted spraying at a concentration of $5 \%$ to standardize the sprouting,

\section{Conduction of experiment}

Duration of days was evaluated after pruning of the main vine phenologic phases, using the scale proposed by Eichhorn and Lorenz (1984). Two evaluations were performed a week until flowering and, after that phase, such evaluations were once a week. From visual observations of the phenologic phases, the period between pruning and the beginning of sprouting, full flowering with $50 \%$ flowers opened, beginning of maturation (veraison) and maturation (harvest), visually mature fruits and content of soluble solids above 14을.

\section{Statistical analysis}

Statistical analysis was performed using the SAS (Statistical Analysis Software, version 9.2) system. Multivariate analyses, such as the correlation between the variables $(p<$ 0.01), principal component analysis (PCA) and the UPGMA clustering method were obtained from dissimilarity matrix computed by Euclidean distance and used to classify the genotypes per the productive cycle. The minimum criteria absorption on $80 \%$ of total variation was used in the first components (Cruz and Regazzi, 1994).

\section{Conclusion}

The starting maturation and maturation are the most divergent periods between the grapes phenotypes. The PCA jointly with the group by the UPGMA method classified the phenotypes according to three different productive cycles. In that way, 25 genotypes were classified as early, 75 as median and 10 as late. The grapes phenotypes evaluated had good variability regarding the productive cycle.

\section{Acknowledgements}

Research supported by the Coordenação de Aperfeiçoamento de Pessoal de Nível Superior (CAPES).

\section{References}

Abe LT, Mota RVD, Lajolo FM, Genovese MI (2007) Phenolic compounds and antioxidant activity of Vitis labrusca and Vitis vinifera cultivars. Ciênc Tecnol Aliment. 27(2):94-400.

Agasse A, Vignault C, Glissant D, Conde C, Geros H, Delrot S (2007) Molecular aspects of sugar transport and its regulation during grape berry ripening. In: Jeandet $P$, Clément C, Conreux A(Eds) Macromolecules and Secondary Metabolites of Grapevine and Wine, Intercept, Lavoisier, Paris. 12-22.

Anzanello R, Souza PVDD, Coelho P F (2012) Fenologia, exigência térmica e produtividade de videiras' Niagara Branca','Niagara Rosada'e'Concord'submetidas a duas safras por ciclo vegetativo. Rev Bras de Frut. 34(2):366376.

Arora R, Rowland L, Tanino K (2003) Induction and release of bud dormancy in woody perennials: a science comes of age. HortScience. 38(5):911-921.

Barros LB, Margoti G, Fowler JG, De Mio LLM, Biasi LA (2015) Thermal requirement and phenology of different cultivars of Vitis labrusca on different rootstocks. Sem. Ciênc Agrár. 36(4):2433-2442.

Borges RME, Alves EODS, Gonçalves NPDS, Gomes APDO, Andrade DCL, Albuquerque, TCSD (2010) Phenotypic divergence among wine grape accessions in the semi-arid region of Brazil. Crop Breed Appl Biotecnol. 10(3):260-265.

Botelho RV, Pires EJP, Terra MM (2002) Qualidade da uva de mesa 'Vênus' tratada com thidiazuron. Ceres. 49(286):629639. 
Camargo UA, Dias MF, Dal Conte AF, Mandelli F, Lovate PJL (1994) Dona Zilá e Tardia de Caxias: uvas tardias para mesa. Embrapa Uva e Vinho. Comunicado Técnico. 14:1-4.

Camargo UA, Mandelli F (1993) Vênus: uva precoce para mesa. EMBRAPA-CNPUV. Comunicado Técnico. 13:1-4.

Castelli S, Pisani PL (1985) Observations on the blossom of grapevines. VigneVini.12:23-25.

Cerqueira-Silva CBM, Cardoso-Silva CB, Nonato JVA, Corrêa RX, Oliveira AC (2009) Genetic dissimilarity of "yellow" and "sleep" passion fruit accessions based on the fruits physical-chemical characteristics. Crop Breed Appl Biotecnol. 9(3):210-218.

Conde C, Silva P, Fontes N, Dias ACP, Tavares RM, Sousa MJ, Agasse A, Delrot S, Gerós H (2007) Biochemical changes throughout grape berry development and fruit and wine quality. Global Sci books. 1(1):1-22.

Coombe BG (2001) Ripening berries - a critical issue. Australian Viticulture. 5:28-33.

Cozzolino D, Cynkar WU, Shah N, Dambergs RG, Smith, PA (2009) A brief introduction to multivariate methods in grape and wine analysis. Int J Wine Res. 1(1)123-130.

Cruz CD, Regazzi AJ, Carneiro PCS, Cruz C, Regazzi J, Carneiro $P$ (2004) Divergência genética. Modelos biométricos aplicados ao melhoramento genético. Viçosa: UFV. 377413.

Eichhorn KW, Lorenz DH (1984) Phaenologische Entwicklungsstadien der Rebe. European Med Plant Protection Org. 14:295-298.

Gama RDS, Santos CAF, Dias, RC (2013) Genetic variability of watermelon accessions based on microsatellite markers. Gen Mol Res. 12(1):747-754.

George AP, Nissen RJ, Baker JA (1988) Effects of hydrogen cyanamide in manipulating budburst and advancing fruit maturity of table grapes in south-eastern Queensland. Animal Prod Sci. 28(4):533-538.

Halaly T, Pang X, Batikoff T, Crane O, Keren A, Venkateswari J, Or E (2008) Similar mechanisms might be triggered by alternative external stimuli that induce dormancy release in grape buds. Planta. 228(1):79-88.

Köse B (2014) Phenology and ripening of Vitis vinifera L. and Vitis labrusca L. varieties in the maritime climate of Samsun in Turkey's Black Sea Region. South African J Eno Viti. 35(1):90-102.
Leão PCDS, Cruz CD, Motoike SY (2011) Genetic diversity of table grape based on morpho-agronomic traits. Scientia Agricola. 68(1):42-49.

Lebon G, Duchene E, Brun O, Clement C (2005) Phenology of flowering and starch accumulation in grape (Vitis vinifera L.). cuttings and vines. Annals of Botany. 95:943-948.

Migicovsky Z, Sawler J, Money D, Eibach R, Miller AJ, Luby JJ, Wührer W (2016) Genomic ancestry estimation quantifies the use of wild species in grape breeding. BMC Genom. 17(1), 478.

Sánchez-Mora FD, Saifert L, Zanghelini J, Assumpção WT, Guginski-Piva CA, Giacometti R, Nodari RO (2017) Behavior of grape breeding lines with distinct resistance alleles to downy mildew (Plasmopara viticola). Crop Breed Appl Biotechno., 17(2),141-149.

Or E, Vilozny I, Eyal Y, Ogrodovitch, A (2000) The transduction of the signal for grape bud dormancy breaking induced by hydrogen cyanamide may involve the SNF-like protein kinase GDBRPK. Plant Mol Biol. 43(4):483494.

Sousa JS (1959) Somatic mutations of the Niagara grape in Brazil. Bragantia. 18:387-415.

Taiz L, Zeiger E (2009) Transporte de soluto. In: Taiz L, Zeiger E. Fisiologia vegetal. In Fisiologia vegetal. Artmed. 131-139.

Tecchio MA, Moura MF, Hernandes JL, Paioli-Pires EJ, Terra $\mathrm{MM}$, Leonel S (2009) Efeito do ácido giberélico nas características ampelométricas dos cachos de uva 'A Dona'e 'Marte'. Scientia Agraria. 10(3):297-304.

Töpfer R, Hausmann L, Harst M, Maul E, Zyprian E, Eibach R (2011a) New horizons for grapevine breeding. In Flachowsky $\mathrm{H}$ and Hanke MV (Eds) Fruit, vegetable and cereal science and biotechnology. Methods in temperate fruit breeding. Global Science Books, Isleworth, (5)79-100.

Van Leeuwen C, Darriet P (2016) The impact of climate change on viticulture and wine quality. J Wine Eco.11(1), 150-167.

Vanderborght T (1988) A centralized database for the common bean and its use in diversity analysis. In Genetic Resources of Phaseolus Beans. Springer Netherlands. 5156.

Vasconcelos MC, Greven M, Winefield CS, Trought MC, Raw $\checkmark$ (2009) The flowering process of Vitis vinifera: a review. Amr J Eno Viti. 60(4):411-434.

Wan Y, Schwaninger H, He P, Wang Y (2015) Comparison of resistance to powdery mildew and downy mildew in Chinese wild grapes. VITIS-GEILWEILERHOG. 46(3)132-136. 